IJLR: International Journal of Law Recontruction

Volume 4, Number 1, April 2020

DOI : $10.26532 /$ ijlr.v4i1.8310

\title{
RECONSTRUCTION NEW PARADIGM FOR MANAGEMENT AND DEVELOPMENT OF WAQF
}

\author{
Muhammad Samsuri \\ Sultan Agung Islamic University \\ moh.syamsuri@gmail.com \\ Ahmad Khisni \\ Sultan Agung Islamic University \\ ahmad.khisni@unissula.ac.id \\ Mahmutarom \\ Wahid Hasyim University \\ mahmutaromhr@yahoo.co.id \\ Anis Mahdurohatun \\ Sultan Agung Islamic University \\ anism@unissula.ac.id
}

\begin{abstract}
Waqf is a religious institution in Islam, and is included in the category of community worship which is a means and capital is essential to promote the development of religion. Evidence used as the basis sharia endowments text derives from an understanding the Qur'an and Sunnah. Then understand and using law endowments not merely textual law or figh, but must dare to seek renewal of the schools endowment to be able to prosper the people, because the basic assumption of the law is an institution that aims leads man to life a fair, prosperous and make human happy. The type of research is socio legal research is explorative, descriptive. With the approach of the law and the case approach, Source data: derived from the primary data, that is data obtained from field practice. The development of waqf law reform must begin with a deeper studies of waqf as ijtihadi region, as well as the legal principles of waqf is a truth that is used as the foundation of thinking and reason opinion, the reform ideology, law enforcement and implement a waqf.
\end{abstract}

Keywords: Reconstruction, Management Development, Waqf

\section{A. INTRODUCTION}

Waqf is a philanthropic Islam which need to be empowered for the benefit of the people. Waqf have practiced ancient society since before Islam, although at that time, they used another name (not using waqf, because they have ancient social structure). But, we will found The evidenced about this concept by the many archeological places of worship which permanently 
established to support the activities of worship. Just from this way it shows the same thing with the essence of waqf. ${ }^{1}$ On Islamic law concept, endowments included in the category of community worship. Throughout the history of Islam, means as capital endowments which very important to promote the development of religion. Forming the social problems of Indonesian society and the demands from the economic wellbeing at this time, describe that the concept would be showing the existence in the part of view from strategic endowments agency, as well as one aspect of the spiritual dimension of Islam, and also given us doctrine that emphasizes economic welfare (social dimension).

Historical development of waqf in Indonesia are basicly on basis with the spread of Islam throughout the archipelago ${ }^{2}$. Besides doing the propagation of Islam, the scholars also teach endowments to the people. The need for a place of worship, such as mosques, surau, encourages Muslims to gave up their lands as endowments or waqf. Doctrine endowments in the archipelago continues to grow as evidenced by the many historic mosques built on land waqf. Along with the social development of the Islamic community, the practically from waqf still progress for along time. ${ }^{3}$

Waqf is an Islamic religious institution which already established and settle as a formal secure institution based on religious (Islamic) law. In the same chapter on Islamic law studies, the endowments/waqf is one of the principalcategory from community worship (worship ijtimaiyah). Throughout the history of Islam, this concept is pointed views as heavy issues which endowments are very important to promote the development of religion. In the midst of the social problems of Indonesian society and guidance will become an economic prosperity, and pursued the existence of waqf institutions to be more strategic, as well as one of the aspects of spiritual dimention of Islamic teachings, and also utilisize as a doctrine that emphasizes economic welfare (social demention).

In terms of Personality ('in general), endowments/waqf is the kind of giving that implementation is done by retaining (ownership) of origin (tahbisul Ashli), and then make its benefits are generally accepted. Ashli Tahbisul hold goods to gave by endownments means that is not inherited, sold, assigned, mortgaged, leased and the like, while the usageand utility have to accordance with the willness of wakif without reward. ${ }^{4}$

There are several problems in waqf, if an inventory that had been developed in the community such as a lack of understanding and awareness among Muslims against waqf. Since the advent and rise of Islam in Indonesian endowments have been practiced by understanding adopted community which understands Shafi'ites and local custom. The pattern of implementation waqf on Indonesian Islamic community still uses propperly, such as legal actions for

1 Muhammad Abu Zahra, Muhadharat fi al-Waqf, Dar al Fikri, Cairo, 1971, P.5

2 Ahmad Mansur Suryanegara, Fire History, Pustaka Salamadai Universe, Bandung, 2009, P. 99

3 Andi Supreme Prihatna et al., Waqf God and Agenda for Humanitarian Studies of the Waqf in the Perspective of Social Justice in Indonesia, Center for the Study of Religion and Culture of UIN Syarif Hidayatullah, Jakarta, 2006, P. 71.

4 Sayyid Sabiq, Fiqh al-Sunnah, (Cairo: Dar al-Turas Maktabah, the Section VI), P.427 
waqf land which designed in oral agreement on the basis of mutual trust to a person or a particular institution, the habit of observing endowments as good deeds and have value precious before God without having to perform administrative procedures and waqf property deemed to belong God alone that anyone would not dare interfere with accountability without the permission of Allah. Similarly, on the goods being waqf only fixed objects which are used tobe waqf, such as land, building of mosques, madrasas, schools, cemeteries, hospitals, orphanages and others. Therefore redefinition of ideology needed so waqf endowments have meaning more relevant with the real situation in the public welfare issue.

\section{B. Research Methods}

The type of research is socio legal research is explorative, descriptive. With the approach of the law (State Approach) and the case approach (Case Approach), Source data: derived from the primary data, that is data obtained from field practice. Secondary data obtained through literature studies and documentary studies. The data collection technique is done by observation, direct observation from various cases and in-depth interview. Technical Data Analysis: conducted qualitatively-inductive, also conducted a quantitative analysis. $^{5}$

\section{DISCUSSION}

\section{Waqf as a model ijtihadi}

Good management and develop of waqf in Islamic law, is covred from the territory ijtihadi, ${ }^{6}$ because there are no verses in the Qur'an and Sunnah that clearly explains the doctrine of waqf. Evidence used as the basis laws and syariah basic endowments text derives from an understanding the Qur'an and Sunnah. According to Mustafa Ahmad Zarqa 'in his book Ahkam a-Waqf, the overall arrangement related to the issue is a matter ijtihadiyah endowments, so that in practice allows innovations which held both in its conception and practice management. ${ }^{7}$

Similarly, in terms of legal powers possessed, endowments doctrine teaching that is just only a recommendation (sunnah), not mandatory, although waqf has the potential to be a milestone for running the welfare of the community. Thus, the doctrine of waqf included in the ijtihadi, and naturally become non-managerial support that can be developed optimally managed. ${ }^{8}$

Postulate on which the endowments on syaria concept began from the text which comes from understanding the Qur'an and Sunnah. There is nothing in the Qur'an or Sunnah that clearly explains the doctrine of waqf. As with the teachings of charity that are described in the Qur'an and Sunnah. Even with regard to the technical operations of charity, such as the

5 Zainudin Ali, 2016, Legal Research Methods. Sinar Grafika, Jakarta, 2016, P 7.

6 Abdul Wahhab Khallaf, Usulu Science Of Figh, An-Nasr wa Tauzi, Cairo, 1978, P.216

7 Ahmad Mustafa Zarqa, Ahkam al-Waqf, Dar al-Imara 1, Cairo, P. 45-46

8 Ministry of Religious Affairs, Endowments New Paradigm in Indonesia, Directorate of Zakat and Waqf Director General of Hajj and Islamic Guidance, Jakarta, 2004, P.28 
types of goods that harsus Zakat, pattern-making, the parties are entitled (mustahiq) got it, described in detail by texts that so much. So that the teachings of charity placed as one aspect of the teachings of Islam which qath'iyyu ad-dilalah, ${ }^{9}$ although in many cases, technical operationalization of zakat management experience as an effort to empower numerous innovations to optimally upgrading the existing conditions.

The doctrine of waqf not explicitly and in detail described in the Qur'an, and none of the verses in the Qur'an which is silent on the word "waqf". The main basic teachings disyariatkannya endowment is by understanding based on the context of the Koran, that endowment as a gooddeeds.

From some verses and sayings of the Prophet which offend the waqf issue appears to be too strict and few laws endowments are set based on both sources. So the doctrine of waqf is not placed on the territory ta'abudi, ${ }^{10}$ but are ijtihadi, especially with regard to aspects of management and development. Discussion on the management and development of endowments made since the time of the Imams mujtahidin Khulafaurasyidin until now exercised through their ijtihad, using various methods of ijtihad are manifold, as mqashid ash-Shariah, qiyas, maslahah mursalah, and others. The interpretation that is often raised by the scholars, that the endowments it is synonymous with shadaqah jariyah, namely an act of worship that has rewards that continue to flow as long as they can be used by human life. ${ }^{11}$

Since the problem of management and development of endowments, including a law (teachings) of Islam who entered the ijtihadi, then it becomes extremely flexible, open to new interpretations, dynamic, futuristic (future-oriented). Thus, from the aspect of the teachings of course, the waqf is a huge potential to be developed according to the needs of the times. Moreover, the teachings of this waqf including parts of muamalah have a very wide range.

\section{New Paradigm Principles of waqf}

a. Principle of Immortality Benefits

Views of Imam sect in waqf fiqh issues greatly affect the public's understanding of Islam (especially Indonesia) and often understanding of waqf less proportionately. Imam Malik and Imam Shafi'i more primarily and stressed the importance of immortality concept of waqf objects, although it has been severely damaged.12Malikiyah groups found not to be exchanged waqf property consisting of immovable property, even if it gets damaged or does not produce anything. But some scholars have argued Malikiyah be agree when it is no longer

9 Yahya and Fatchurrahman Mukhtar, Law Development Basics of Islamic Fiqh, PT. Al Ma'arif, Bandung, 1982, P. 37

10 A, Khisni, development of ideas Islamic Law, Unissula Press, Cet. Second, Semarang, 2015, P.2

11 Ahmad Rofiq, Islamic Law in Indonesia, PT. King Grafindo Persada, Jakarta, 1995, P.312

12 Ibid. 
useful and replaced with other immovable objects. ${ }^{13}$ As for moving objects, classes Malikiyah Groups allow swapping, because the presence of the object endowments exchange it may be more beneficial and would not be in vain ${ }^{14}$

Opinion Imam Ash-Shafi'i in exchange of waqf property problems similar to the opinion of Imam Malik, which is extremely prevents the exchange of objects / waqf property. Imam Shafi'i believes absolutely should not trade or sell the mosque, even though the mosque would be damaged or destroyed. ${ }^{15}$

The principle of eternity the benefits seem to have started as well as in opinion to be used as guidance in the management and development of endowments, which adopted by the Yayasan Sultan Agung Semarang Waqf Board, that the management of waqf should be with faith and science, as well as laid out in congregation (rows) is good. It is very fundamental, because endowment assurance implies preservation and propagation of Islamic struggle. Some of the policies pursued strategies are:

1) Maintaining the benefits immortality waqf property;

2) Develop the benefits of waqf property;

3) Transparency in the management of waqf property;

4) Accountable in the management of waqf, and

5) The necessary network Waqf (waqf networking).

Application of the principle of immortality these gains are likely in line withthe necessity guided by al-maslahah in doing istinbath law. AlGhazali explained that applying the law based al maslahah it entrenches the law with something that brings benefit (profit) and keep madharat (damage),16 and the nature of maslahah is: "Maintaining the purpose of Personality '(in establishing law)", while the purpose of Personality' includes five basic staple, namely;

1) Protect the religious (hifdu al deen);

2) Protect the soul (hifdu al nafs);

3) Protect it (hifdu al aql),

4) Protect the health of humans (hifdu al nasl),

5) Protects the property (hifdu al mal). ${ }^{17}$

While Al-Khwarizmi explained that al maslahah namely maintaining the purpose of Personality (in establishing law) in a way to avoid damage from humans. Second opinions have in common in terms of its meaning and purpose, because it implies resist damage draw benefit, and refuse the benefit means pulling damage. ${ }^{18}$

13 Muhammad Abu Zahra, Muhadlarat fi al-Waqf, Dar al-Fikr al-Arabi, Beirut, 1971, P.168

14 Muhammad Jawaad Mughniyah, al-Ahwal al-Syakhsiyah al_mazhahib alaa al-khamsah, Dar al-IIm li Malayin, Beirut, 1964, P.333

15 Imam Abi Muhyiddin ibn Zakariya al-Nawawi Nerve, Al-Majmoo 'Sharh al-Muhadzdzab, Dar al-Fikr, Juz 4, Beirut, 2000, P.54-55

16 Said Rahman al Buthi, Dhawabith al-Maslahah, Dar al-Fikr, Beirut, P. 27

17 Nasrun Haroen, Usul Figh 1, Logos Discourse Studies, cet.2, Jakarta, 1997, P.114

18 Amir Syarifuddin, Usul Fiqh, Logos Discourse Studies, Volume 2, Cet. 5th, Jakarta, 2009, P.346 
According to a tradition, the Prophet began to build a mosque (Nabawi mosque) begins with building when a camel place he stopped on his arrival in Medina, namely in Mirbad, purchased a plot of land that the companions of the Prophet worked together from belonging to two orphan care As'ad bin Zararah, After that the mosque was built in a very simple form. The floor is made of gravel and sand, the roof is made of palm fronds and pillars made of palm trunks. ${ }^{19}$ Over time, after several years and centuries later the mosque undergone renovationrefurbishment in stages by government leaders in the medina. The Prophet and his followers do not let just early buildings Nabawi mosque become damaged and eventually collapsed and maybe lost causing time for reasons as cultural heritage preservation or maintenance of objects endowments, but held a reshuffle which is a necessity in order to achieve the benefit of the wider for Muslims.

The principle of eternity the benefits of object is important because religious waqf endowments worship categorized as having a value reward continuous flow though wakif (people who waqf) had died. An object is considered to have immortality benefit endowments, there are at least four things must exist, among others: ${ }^{20}$

1) The waqf objects can be used by many people. For example, donations of land to set up madrasas / schools, boarding schools, economic development and others.

2) Wakaf give a more real value to the wakif itself. Materially, the wakif entitled (should) utilize objects such as waqf also applies to recipients of other endowments. In immaterial, the wakif is definitely going to get double the reward value and sustainable for objects submitted.

3) Benefits immaterial endowments objects beyond material benefits. Or it could be reworded simply that the value of the extrinsic object endowment exceeds its intrinsic value. Because the pressure point endowment itself is actually more important function for others (many) of the object itself.

4) Property endowment itself does not make or lead to danger (madharat) to another person (recipient waqf) and also wakif own.

\section{b. Principle of Accountability}

The principle of accountability is based on the idea that the endowment is worship have divine dimension and insaniyah, it needs to be accountable to implementation for Allah. As fellow human beings, in

19 Muhammad Husayn Haykal, Hayat Muhammad, trans, Ali Ouda, Living History Muhammad, PT Litera Antar Nusa, Cet. 29, Jakarta, 2003, P.193

20 Abdul Manan, Assorted Civil Law Issues Islam in Indonesia, Kencana Prenadamedia Group, jakarta, 2014, P. 261 
this world and in the hereafter. Form of responsibility for the management and development of endowments based on: ${ }^{21}$

1) Responsibility to God.

Wakif and Nazhir behavior in the management and development of endowments is appropriate and not with Shari'ah rules will be asked justified. All actions and tasks undertaken by the parties related to wakaf have transendetal consequence, which must be justified before God Almighty. The consequences of vertical accountability is based on:

And Indeed, they will bear the burden (sins) they, and burdens (of sin others) in addition to their own burdens, and Indeed, they will be asked on the Day of Resurrection about what they used to invent. QS. An-Ankabut (29): 13. ${ }^{22}$

And surely you will be questioned on the matter is something that you do". Qs. an-Nahl (16): $93 .^{23}$

Accountability to God is very important and the basis of all subsequent liability. If a person's own responsibility to God, in any position, then he would base his intentions outright. And sincerity for each position has its own portion. For a wakif, he will feel sincere and very loose in performing endowments, without hope of worldly for his actions and only would please Allah SWT. As for a Nazhir, what the responsibilities will be carried out in earnest, professional, qualified and based on sincere intentions. The key to success is the principle in the form of their sincerity, that all behavior in the management and development of endowments preceded by a sincere intention for Allah.

2) Institutional responsibility.

In this form, of the manager of waqf (Nazhir) is ultimately responsible to God and to those who have authority, namely the institution of higher levels of the organization in accordance with the management and development of endowments. Organization management and development/empowerment waqf in Indonesia consists of Indonesian Waqf Board and the Institute of Nazhir's all. Each institution has sub-organizations of the management and development, which should be responsible institution to highest institution above. Organizational control functions should be run well so that the trust was being carried can be optimally satisfied. This institutional mechanism as an attempt to eliminate the deviation of the objects of waqf. ${ }^{24}$ Therefore, you should Nazhir institutional form (organization) official, though not negate individuals limits being Nazhir at least 3 people (chairman, secretary and treasurer) as

21 Abdul Manan, Assorted Civil Law Issues Islam in Indonesia, P. 261-263

22 Department of Religious Affairs, Al-Qur'an and Terjemahnya, Yayasan Organizers Translator Qur'an, Bandung, Gema Treatise Press, Jakarta, 1989, P. 830

23 Ibid.

24 Abdul Manan, Assorted Civil Law Issues Islam in Indonesia, P. 262

IJLR, Volume 4, Number 1, April 2020 
stipulated by Law No. 41 of 2004 on Waqf. ${ }^{25}$ It is intended to maximize the role of Nazhir and pengawasaanya in developing perwakafan. From the aspects of the management and development of endowments by the Indonesian Waqf Board and all Nazhiran institutions will form the principle of institutional accountability Nazhiran all.

3) Legal liability

Legal responsibility have a very broad aspect, not only regarding matters set out in the positive law, but concerning all things that have been set explicitly in the Shari'ah of waqf. ${ }^{26}$ Therefore, management and development of endowments should not deviate from all the provisions that have governed it. Legal liability is the responsibility carried by the channels and the provisions of applicable law. By law, the concerned should be ready for submission to the court if it turns out later in the implementation of the mandate violates the rules of the applicable law.

4) Social responsibility.

Social responsibility is closely linked to the moral life of society in general. Nazhir action in managing and developing endowments must be morally responsible to the community that is safe actions which do not damage the social norms that exist in society. A Nazhir should be aware that attitude and his actions everyday to be an example for the surrounding community. Similarly, in the management and development of endowments should not be used for the benefit of vice and other evil deeds, which are detrimental to people's lives. Social accountability is synonymous with adherence to social norms that develop in the midst of society, that is to cultivate a shame when wakafnya not develop and embarrassed when everyday actions injure the moral values of society. The consequences of this social responsibility is very heavy; because it is directly or indirectly a wide range of behavior management of waqf supervised by the public at large, in addition to the supervision of the supervisory board is attached by the authorities.

c. Principle of Professionalism management

Everything works if implemented with good management and the right will produce output that is good also. Similarly, in the management of waqf development, management occupies the most urgent position. Pattern management waqf endowments determine the objects that have been more helpful or not. Management of objects endowments have only managed to use the "trust management" and centralism leadership override aspects of supervision, the benefits of waqf property is also considered less than optimal. It is necessary in a modern waqf management that offers a more professional management system, which is used as the spirit of the management of waqf objects in order to take

25 See chapters 9 and 10 of Law No. 41 of 20014 on Endowments 26 Abdul Manan, Op.Cit, P.263 
the benefit of a wider and more real for the good and interest of the people. $^{27}$

Management is a process that is done by mobilizing all resources to realize the objectives that have been defined. ${ }^{28}$ So that management is a process that is done through planning, organizing, leadership, and oversight by mobilizing resources of the organization in order to achieve the goals set. Medium according to George R. Terry, Management is a typical process, which consists of actions: planning, organizing, actuating, moving, and controlling (supervision), which is performed to determine and achieve goals- the target set through the utilization of human resources and other sources. ${ }^{29}$ In the matter of endowments/waqf, necessary for the management effort for management valuabilities and development of endowments can achieve a productive, high quality, effective and efficient,

Similarly Nazhir both individually and institutionally will work well if showing a portrait of good management leadership, which could be seen from three aspects: ${ }^{30} 1$ ) transparency; The transparency of leadership in kenazhiran institution should become a tradition for the closing act of dishonesty, corruption, manipulation and so forth. 2) Public Accountability (Public Liability); is a form of execution shidiq properties (honesty) and trustee (the trust). Because trust and honesty must be accountable in this world and in the hereafter. 3) Aspirational; willing to listen and accommodate the dynamics of institutions nazhir d. Principle of Social Justice

Waqf As one aspect of the social dimension of Islamic teachings and occupies an important position as an effort to build a just social system and welfare, Duty to eradicate poverty is an obligation for those people who have the ability than others whose unfortune in economically conditions. So in order to empower the weak economy of Muslims, are strongly encouraged to undertake social worship like charity, donation and using jariyyah. Endowments/waqf occupy a major role after the charity as a community empowerment of weak economy of the society. The idea of helping the weak in order to remain alive to provide for themselves and their families every day to do the charity, while empowering them more widely to improve the lives of everyday sufficient merely to do with endowments waqf.

Sense of justice is an abstract and relative value, ${ }^{31}$ but it demands a positive action and the action and concrete. Implementation of the

27 Mardani, Islamic Law: Zakat, Infak, Dole, and Endowments, PT Citra Aditya Bakti, Bandung, 2016, P. 168

28 Ahmad al-Shabab, Productive Endowment Management, RajaGrafindo Persada, Jakarta, 2015, P.73.

29 Wayne K Hoy, Educational Administration; Theory, Research and Practice, Mc Graw Hil CAMPANIES, New York, 2001, P.32

30 Ministry of Religious Affairs, Op.Cit, P.84

31 Mahmutarom HR, Reconstruction of the Concept of Justice, Studies on Protection Against Crime Sacrifice Lives in Positive Law, Islamic Law, Public Construction and International Instruments, (Semarang: Diponegoro University Board Publishers, 2016), P.31 
endowment is one concrete example on a sense of social justice, because the endowment is a gift freely a number of well-loved possessions for the common good. A wakif charged with high sincerity to hand over its assets to be given as a waqf property in order to provide benefits to the community at large in the public interest. Without boosted their sense of social justice then how strong the sense to remove property/ wealth in the form of endowments for others.

Social impact of the implementation of religious endowments can be seen from two sides, namely: first, in terms of wakif (people who donated his property), with a pilgrimage to the social as endowments automatically he had tried to cleanse his soul of the properties of asocial as curmudgeonly, miserly, selfish, greedy, and encourage them to be social as like helping people who can not afford economically and likes to make sacrifices for the common good. ${ }^{32}$ Second, from the party receiving the endowment, that the existence of waqf property that can be taken advantage to meet the needs of life, will eliminate the vices that may be buried deep in the heart as envy, jealousy, hate, and plot against those who are considered capable of economically and can strengthen the brotherhood between rich and poor. ${ }^{33}$

The social function of waqf is that the use of the property of a person should benefit directly or indirectly to the public. In Islam emphasized that the ownership of the property (land) is included in it something else, which means that in one's wealth is no other people's rights attached to such assets, as referred to in Surat adh-Dzariyat, verse 19 which means:

"And in their property, there is a right for people who ask (because they have) and for people displaced". (Surah adh-Dzariyat (51): 19)

By pilgrimage endowments will have a positive influence and dynamic of the life that foster a sense of social responsibility, to avoid the influence understand negative as capitalism that brought on the attitude of selfish, individualistic, and communism were inciting class people and the poor with the rich and the government. The basic principles of worship endowment aimed at creating social justice is an implementation of the economic system that encourages and recognizes the property rights of individuals and communities equally aimed at creating social justice.

The concept of social justice espoused by Islam is also the principle of a new paradigm of endowments, that if we are donating some wealth for the endowment means social justice more equitable, not just focused on the aspect of a person's sheer generosity. And because it has a fundamental principle, the endowment should be managed professionally so do not be piles of treasure that little or no benefit to the general public.

32 Abdul Manan, Assorted Civil Law Issues Islam in Indonesia, p. 265 33 Ministry of Religious Affairs, Op.Cit, P 87 


\section{CONCLUSSION}

Waqf is an Islamic religious institution in already established. In Islamic Law concept, endowments waqf included in the category of community worship (worship ijtimaiyah). Throughout the history of Islam, is a means and capital endowments are very important to promote the development of religion, and the existence of waqf institutions to be very strategic, as well as one of the aspects of spiritual dimension on Islamic teachings, is also a doctrine that emphasizes economic welfare (social dimension). There are several problems in endownments waqf, if an inventory that had been developed in the community, among others, lack of understanding and awareness among Muslims against endowments, both concerning the development of the understanding of the basic concepts of law endowments, management, development, and safeguarding of assets endowments. Therefore redefinition of ideology needed so waqf endowments have meaning more relevant with the real situation in the public welfare issue. Redefinition of the schools endowment should start and begin from the premise that the conceptmanagement arrangements and the development of waqf in Islamic law, entered the region in the implementation ijtihadi thus enabling held innovations both in its conception and practice management. Similarly, the need to be heldassessment and re deepening the principles of the new paradigm law of waqf covers immortality benefit principle, the principle of accountability, professionalism management principle, and the principle of social justice

\section{BIBLIOGRAPHY}

\section{Book:}

Abdul Manan, 2014, Assorted Civil Law Issues Islam in Indonesia, Kencana Prenadamedia Group, Jakarta;

Abdul Wahhab Khallaf, 1978, Usulu Science Of Fiqh, An-Nasr wa Tauzi, Cairo;

Ahmad al-Shabab, 2015, Productive Endowment Management, RajaGrafindo Persada, Jakarta;

Ahmad Mansur Suryanegara, 2009, Fire History, Pustaka Salamadai Universe, Bandung;

Ahmad Mustafa Zarqa, Ahkam al-Waqf, Dar al-Imara 1, Cairo;

Ahmad Rofiq, 1995, Islamic Law in Indonesia, PT. King Grafindo Persada, Jakarta, 1995

Akhmad Khisni, 2015, development of ideas Islamic Law, Unissula Press, Cet. Second, Semarang;

Al-Bukhari, Sahih Bukhari, the Section IX, pp 263, Hadith No. 2532 (Version Maktabah Syamilah);

Amir Syarifuddin, Usul Fiqh, Logos Discourse Studies, Volume 2, Cet. 5th, 2009, Jakarta;

Andi Supreme Prihatna et al., 2006, Waqf God and Agenda for Humanitarian Studies of the Waqf in the Perspective of Social Justice in 
Indonesia, Center for the Study of Religion and Culture of UIN Syarif Hidayatullah, Jakarta;

Department of Religious Affairs, 1989, Al-Qur'an and Terjemahnya, Yayasan

Organizers Translator Qur'an, Bandung, Gema Treatise Press, Jakarta;

Imam Abi Muhyiddin ibn Zakariya al-Nawawi Nerve, 2000, Al-Majmoo 'Sharh al-Muhadzdzab, Dar al-Fikr, Juz 4, Beirut;

Mahmutarom HR, Reconstruction of the Concept of Justice, Studies on Protection Against Crime Sacrifice Lives in Positive Law, Islamic Law, Public Construction and International Instruments, (Semarang: Diponegoro University Board Publishers, 2016);

Mardani, 2016, Islamic Law: Zakat, Infak, Dole, and Endowments, PT Citra Aditya Bakti, Bandung;

Ministry of Religious Affairs, 2004, Endowments New Paradigm in Indonesia, Directorate of Zakat and Waqf Director General of Hajj and Islamic Guidance, Jakarta;

Muhammad Abu Zahra, 1971, Muhadharat fi al-Waqf, Dar al Fikri, Beirut;

Muhammad Husayn Haykal, Hayat Muhammad, trans, Ali Ouda, 2003, Living History Muhammad, PT Litera Antar Nusa, Cet. 29, Jakarta;

Muhammad Jawaad Mughniyah, 1964, al-Ahwal al-Syakhsiyah al_mazhahib alaa al-khamsah, Dar al-Ilm li Malayin, Beirut;

Nasrun Haroen, 1997, Usul Figh 1, Logos Discourse Studies, cet.2, Jakarta;

Sayyid Sabiq, Fiqh al-Sunnah, Dar al-Turas Maktabah, the Section VI, Cairo;

Wayne K Hoy, 2001, Educational Administration; Theory, Research and Practice, Mc Graw Hil CAMPANIES, New York;

Yahya and Fatchurrahman Mukhtar, 1982, Law Development Basics of Islamic Fiqh, PT. Al Ma'arif, Bandung;

Zainudin Ali, 2016, Legal Research Methods. Sinar Grafika, Jakarta; 